\title{
DEADLOGKED JURIES AND DYNAMITE: A CRITICAL LOOK AT THE "ALLEN CHARGE"
}

Deadlocks have historically been a problem in jury trials. The solution of the 14th century circuit-riding judge was simply to load the jurors into oxcarts and carry them about with him until a verdict was "bounced out."' More recently, jurors have been prodded by such judicial indiscretions as bread and water diets and jury rooms purposely left unheated in the dead of winter. ${ }^{2}$ Crude methods of forcing verdicts have long gone out of fashion, but more subtle means of jury "coercion" still exist. One of these is known as the "Allen charge."

The Allen charge, often called the "dynamite charge," is a special instruction given to encourage deadlocked juries to reach agreement. The charge was first used in a Massachusetts case in 1851,3 and in 1896 was sanctioned by the Supreme Court in Allen $v$. United States. ${ }^{4}$ The central emphasis of the instruction is usually stated in this manner:

No juror is expected to yield his conscientiously-held opinion. However, if much the larger number is for conviction, a dissenting juror should consider whether his doubt is a reasonable one which made no impression upon the minds of so many men, equally honest, equally intelligent with himself. If upon the other hand, the majority is for acquittal, the minority ought to ask themselves whether they might not reasonably doubt the correctness of a judgment which is not concurred in by the majority. ${ }^{5}$

The purpose of this comment is to consider whether the Allen charge can operate as a coercive influence on the jury, and, if it is capable of of such influence, whether the charge can be subjected to effective appellate review.

"Coercion" in this context means that the charge is capable of causing a minority juror to substitute the majority's opinion for his own-not that he is persuaded to reach a different decision, but that he accepts

1 Crabi, History of English Law 287 (1829).

2 This sort of frontier justice was employed as recently as 1940. See Mead v. City of Richland Center, 237 Wis. 537, 297 N.W. 419 (1941).

3 Commonwealth v. Tuey, 62 Mass. (8 Cush.) 1 (1851).

4164 U.S. 492, 501 (1896).

5 This example of a typical Allen charge is paraphrased from the court's language in the original charge in Commonwealth v. Tuey, 62 Mass. (8 Cush.) 1, 3 (1851). The charge approved by the Supreme Court in Allen v. United States, supra note 4, was quite similar. 
the majority view in spite of his own conviction as to the defendant's guilt or innocence. Claims of such coercive influence are usually based on one of two grounds: First, language is often added to or left out of the charge, distorting the ostensibly "proper" thrust of the approved wording; second, the argument has been made that the charge, no matter how properly phrased, is itself coercive. Most appeals based on the instruction stress the first argument. Appellate courts have reversed where the trial judge failed to include language emphasizing the individual juror's right to retain his conscientiously-held dissenting viewpoint, ${ }^{B}$ or added language emphasizing a "duty to agree." 7 On the other hand, the federal courts have never reversed an Allen charge case solely on grounds that the language and thrust of the central charge were improper, and only an occasional state court has found the instruction coercive on its face. ${ }^{8}$

The courts have, on the whole, favored the use of the charge because it is an efficient tool and, perhaps, because early Supreme Court approval

6 United States v. Rogers, 289 F.2d 433, 436 (4th Cir. 1961).

7 People v. Barmore, 368 Mich. 26, 117 N.W.2d 186 (1962). See also Huffman v. United States, 297 F.2d 754, 759 (5th Cir.) (Brown, J., dissenting), cert. denied, 370 U.S. 955 (1962). Appellate courts have looked with disfavor upon comments from the bench about swallowing one's own view, United States v. Smith, 303 F.2d 341, 343 (4th Cir. 1962), or expressed opinions that the jury should have no trouble reaching agreement, Powell v. United States, 297 F.2d 318, 320 (5th Cir. 1961); Kclsey v. United States, 47 F.2d 453, 454 (5th Cir. 1931).

8 The Kansas court expressly disapproved the charge taken from the original Allen instruction in Eikmeier v. Bennett, $143 \mathrm{Kan} .888,896,57$ P.2d 87, 92 (1936): "To say to a minority that they should re-examine their views in the light of the opinion held by the majority, without putting a like duty on the majority . . . is wrong. The minority may be right and the majority wrong. Until the Legislature provides for verdicts by a definite majority of the jury, the court, by additional instruction, should not suggest, even faintly, that the opinion of the minority is to be controlled by that of the majority." Courts in Idaho, Iowa and Wisconsin have discouraged use of the charge. State v. Moon, 20 Idaho 202, 117 Pac. 757 (1911); Middle States Util. Co. v. Incorporated Tel. Co., 222 Iowa 1275, 271 N.W. 180 (1937); State v. Pierce, 178 Iowa 417, 159 N.W. 1050 (1916). See generally Annot., 109 A.L.R. 72, 85 (1937); Annot., 19 A.L.R.2d 1257, 1262 (1951). Recently a few strong dissenting opinions by federal judges in the Fifth Circuit have objected to the charge as a judicial bludgeon. See the dissents in Andrews v. United States, 309 F.2d 127, 129 (5th Cir. 1962), cert. denied, 372 U.S. 946 (1963); Huffman v. United States, 297 F.2d 754, 755 (5th Cir.), cert. denied, 370 U.S. 955 (1962). Green v. United States, 309 F.2d 852 (5th Cir. 1962), decided within days after Andrews, struck down a use of the charge in the original instructions. The court's opinion in Green was written by Judge Wisdom, the dissenter in Andrews, and, incidentally, the only judge who took part in both cases. But see United States v. Kahaner, 317 F.2d 459, 484 n.18 (2d Cir. 1963), where the Second Circuit expressly disagreed with the recent Fifth Circuit criticisms of the charge. In Kahaner, the charge was repeated at the jury's request, and was nevertheless upheld. It should be noted, however, that the trial court in Kahaner laid great stress on the individual juror's right to retain his conscientiouslyheld opinion. 
gave it an aura of respectability. ${ }^{9}$ One can, however, by examining the reaction of the courts to certain apparent effects of the charge and accompanying practices, see evidence of a judicial attitude that the instruction approaches maximum permissible limits. ${ }^{10}$ An example of this attitude is found in United States $v$. Rogers, 11 where the charge was administered to a jury which had been unable to agree after five hours of deliberation. Fifteen minutes after the instruction was given, the jury returned a verdict of conviction. In reversing, the appellate court said: "The time interval was quite long enough for acceptance of a theory of majority rule, but was hardly long enough to have permitted a painstaking re-examination of the views which the minority had held steadfastly until the charge was given."' 12 One practice which almost always results in reversal is the making of inquiry by the court as to the division of the jury. ${ }^{13}$ Such inquiry, followed by the Allen charge, has been disapproved because it too pointedly directs the charge at a partially identified minority.

While these isolated instances of disapproval indicate an undefined awareness in the impropriety of the instruction, limiting review of the charge to the discernible reaction of the jurors, or to overzealous statements and inquiries by the trial court, ignores the fundamental problem of the Allen instruction-its coercive influence is a function of the context in which it is given, and as such, is always present. The predictable jury reaction to the instruction would be both the reinforcement of the view of the majority, since the charge contains no admonition that majority jurors should reexamine their opinions, and a conclusion on the part of minority jurors that the charge is directed entirely at themthat the weight of judicial prestige is being added to the pressure already exerted by the other jurors. The charge usually comes at a psychological low point in the proceedings when suggestions calculated to bring agreement are apt to be met with less than ordinary critical

9 Often an assignment of error based on the charge is dismissed summarily with a citation to Allen v. United States, 164 U.S. 492 (1896). See, e.g., Andrews v. United States, 309 F.2d 127, 129 (5th Cir. 1962), cert. denied, 372 U.S. 946 (1963); Huffman v. United States, 297 F.2d 754, 755 (5th Cir.), cert. denied, 370 U.S. 955 (1962).

10 United States v. Rogers, 289 F.2d 433, 435 (4th Cir. 1961). Similar comments are found in Green v. United States, 309 F.2d 852, 854 (5th Gir. 1962) ("There is small, if any, justification for its use."); United States v. Smith, 303 F.2d 341 (4th Cir. 1962) ("Unaccented and unembellished, the Allen charge is quite bold enough . . . ."). See also comments of the Kansas court in Eikmeier v. Bennett, 143 Kan. 888, 57 P.2d 87 (1936).

11 United States v. Rogers, supra note 10 , at 436.

12 Ibid.

13 Brasfield v. United States, 272 U.S. 448,450 (1926). The inquiry "can rarely be resorted to without bringing to bear in some degree, serious though unmeasurable, an improper influence upon the jury ....." 
evaluation. A minority member might well take the charge as an invitation to allow the majority to rule.14 At least, there is a likelihood that he will be demoralized by this "official" language urging him to heed the majority. ${ }^{15}$

While the purpose of the Allen charge is to eliminate, where possible, mistrials brought about by hung juries, this is a legitimate purpose only if the change in minority opinion is accompanied by an honest change in its view of the evidence. A change induced by pressure, no matter how subtle, is an unwarranted infringement on the function of the jury. Many states have provided by constitution or statute that jury trials in criminal cases will be by unanimous verdict. ${ }^{16}$ Others, following the federal example, have regarded the unanimity requirement as an integral part of the jury system as it was known at common law, and thus have interpreted state constitutional provisions for "trial by jury" as requiring unanimity. ${ }^{17}$ If unanimity is to have any real meaning in criminal jury trials, each juror must be convinced by the evidence presented of the accused's guilt "beyond a reasonable doubt"18 before the jury can be

14 This was apparently the case in United States v. Rogers, 289 F.2d 433 (4th Cir. 1961). See also Acunto v. Equitable Life Assur. Soc'y of United States, 270 App. Div. 386, 60 N.Y.S.2d 101 (1946).

15 Minimally, the Allen charge furnishes a negative sanction to the majority. No mention is made in the typical Allen instruction of the need for any reevaluation of the majority's point of view. The tone of the charge indicates that any such reevaluation would only take the jury farther from its goal-agreement. If the court creates the impression that it regards the majority view as immutable, then in effect it is conceding that the only remaining possible outcomes are unanimous verdict for the side the majority favors, or mistrial. It would seem that it is the court's duty to refrain from pointing the jury in any direction.

16 Seven states have constitutional requirements for unanimous verdicts in all criminal cases. ME. Const. art. I, § 7; MD. ConsT. D.R. art. 21; N.C. Const. art. I, § 13; S.C. Const. art. V, § 22; UTAH Const. art. I, § 10; VT. Const. art. I, § 10; VA. Const. art. I, \& 8. Several other states require unanimity except in cases not amounting to a felony. Oregon allows conviction by a vote of 10 or more jurors, except in capital cases. ORE. CoNST. art. I, \& 11.

17 Pation v. United States, 281 U.S. 276, 299 (1930). See 3 Blackstone, Commentaries 379 (3d ed. 1884); FED. R. CRIM. P. 31(2). In State v. Robbins, - Ohio -, 189 N.E.2d 641 (1963), conviction by the majority of a three-judge court was reversed on grounds that the defendant, in waiving trial by jury, did not thereby waive trial, and on trial before three judges he retained all statutory rights not waived. The court concluded that the Ohio "reasonable doubt" statute required the assent of all three judges before conviction could be upheld. A case with similar facts is now on review in the New York courts.

18 The reasonable doubt concept had its origins in the 18th century and had become an established part of Anglo-American criminal procedure by the 1820's. For a discussion, see 9 WIGMore, EvideNce $\S 2497$ (3d ed. 1940). See also May, Some Rules of Evidence: Reasonable Doubt in Civil and Criminal Cases, 10 AM. L. Rkv. 642 (1876). Some courts have viewed the unanimity requirement as a function of the reasonable doubt standard. In Hibdon v. United States, 204 F.2d 834, 838 (6th Cir. 1953), the court struck down a majority verdict of conviction reached by consent 
said to be convinced. Under such a view the tentative opinions of a mere majority should have no legal significance. Thus considered, the Allen charge is misleading in that it encourages jurors to take into account a factor outside the evidence-the impact of their own preliminary balloting. They are instructed, late in the proceedings, to reconsider their position in the light of the majority's vote. Yet there is no connection between the majority vote and the reasonableness of an individual juror's doubt. Although it is probably more often true that the majority view reflects the best judgment of the facts, criminal trial decisions are not supposed to rest upon mere probability. ${ }^{10}$

of the parties, saying: "The unanimity of a verdict in a criminal case is inextricably interwoven with the required measure of proof. To sustain the validity of a verdict by less than all the jurors is to destroy this test of proof, for there cannot be a verdict supported by proof beyond reasonable doubt if one or more jurors remain reasonably in doubt as to guilt." In Billeci v. United States, 184 F.2d 394, 403 (D.C. Cir. 1950), Prettyman, J., summarized the relationship of reasonable doubt to the unanimity requirement: "An accused is presumed to be innocent. Guilt must be established beyond a reasonable doubt. All twelve jurors must be convinced beyond that doubt; if only one of them fixedly has a reasonable doubt, a verdict of guilty cannot be returned. These principles are not pious platitudes .... They are working rules of law binding upon the court."

19 Counts v. Commonwealth, 137 Va. 744, 747, 119 S.E. 79, 81 (1923), and cases cited in note 18 supra. The new role given by some courts to the reasonable doubt concept makes the use of the Allen instruction an even greater potential danger to the defendant's rights. The historical view is that reasonable doubt is to be considered by the trial judge in passing upon motions for a judgment of acquittal, and by appellate courts in deciding whether the trial court erred in sending the case to the jury. The courts use the standard to delineate a zone in which the jury can act. The newer view, usually called the Second Circuit rule, confines proof beyond reasonable doubt to the role of an instruction to the jury. The standard is not considered in ruling on the sufficiency of the evidence; at that point there is to be no difference between the rule in civil and criminal cases. If there is substantial circumstantial evidence of each element of an offense, the case is to go to the jury. This Second Circuit rule intensifies the conflict between reasonable doubt and the Allen charge. Under the historic view there is at least the assurance that the court, before entrusting the case to the jury, has already imposed the reasonable doubt standard. Any misinterpretation or coercive effect of the Allen charge is thereby mollified. With proof beyond reasonable doubt removed from the legal test of sufficiency of the evidence, the jury is left, under the Second Circuit view, with the sole responsibility for employing the standard. Adding the Allen charge at this point tends to dilute the effect of the reasonable doubt instruction. Courts would do well to examine the question of whether there is not an essential conflict between the reasonable doubt instruction, which admonishes the jurors that the "burden is upon the prosecution to convince you, beyond a reasonable doubt, that the defendant committed the crime he is charged to have committed," and a charge which questions the reasonableness of any doubt not held by a majority of the jurors.

For a discussion of the criteria applied by the trial judge under both the historical view and the Second Circuit rule, see Goldstein, The State and the Accused: Balance of Advantage in Criminal Procedure, 69 Y YLE L.J. 1149, 1153-61 (1960). Illustrating the historic treatment of reasonable doubt are Rodriquez v. United States, 232 F.2d 819, 821 (5th Cir. 1956); Isbell v. United States, 227 Fed. 788, 792 (8th Cir. 1915). 
Even if the Allen charge might in a given instance coerce a jury, so long as such an effect was infrequent and could properly be singled out for reversal by an appellate court, use of the instruction might still be justified. Many trial devices, improperly used, can result in prejudice to the defendant. The Allen charge, however, does not lend itself to efficient appellate review, as can be seen by examining the factors which have been given weight in past appeals. These include not only the wording of the charge itself, which is subject to near-limitless variations, ${ }^{20}$ but also necessary language that was not included;21 apparent emphasis given various parts of the charge; 22 length of time the jury deliberated before the charge was given;23 length of time after the charge before the verdict was returned;24 and whether the defense objected to the instruction.25 Each new paraphrase of the charge brings up its own questions of propriety, and courts have differed widely in their tolerance for added or substituted language.

The difficulties present in determining the existence of coercion by the length of time the jury spends in deliberation after the charge are self-evident. Fifteen minutes, a court has decided, ${ }^{26}$ is too brief a period for a jury in disagreement to resolve differences "conscientiously." Yet twenty-five minutes has been held to afford ample time for decision without indication of undue influence from the trial judge. ${ }^{27}$ Sometimes problems of wording and the time considerations have been considered together in reviewing the propriety of an Allen charge. These cases apparently hold that overstrong wording in an Allen instruction can be rendered acceptable if the jury nevertheless requires a long period after

Leading Second Circuit rule opinions are United States v. Feinberg, 140 F.2d 592, 594 (2d Cir.), cert. denied, 322 U.S. 728 (1944); United States v. Valenti, 134 F.2d 362, 364 (2d Cir.), cert. denied, 319 U.S. 761 (1943). See also cases cited in Goldstein, supra at $1159, \mathrm{nn} .25,26,28,29$.

20 See, e.g., United States v. Kahaner, 317 F.2d 459, 484 (2d Cir. 1963); United States v. Smith, 303 F.2d 341, 342-43 (4th Cir. 1962); Huffman v. United States, 297 F.2d 754, 757 (5th Cir.) (Brown, J., dissenting), cert. denied, 370 U.S. 955 (1962); Jacobs v. United States, 279 F.2d 826, 828 (8th Cir. 1960); State v. Bozarth, 361 S.W.2d 819 (Mo. 1962); Janssen v. Carolina Lumber Co., 137 W. Va. 561, 73 S.E.2d 12 (1952).

21 United States v. Rogers, 289 F.2d 433, 435 (4th Cir. 1961).

22 Green v. United States, 309 F.2d 852 (5th Cir. 1962).

23 Andrews v. United States, 309 F.2d 127, 130 (5th Cir. 1962) (Wisdom, J., dissenting).

24 Mills v. Tinsley, 314 F.2d 311, 313 (10th Cir.), cert. denied, 374 U.S. 847 (1963); United States v. Rogers, 289 F.2d 433, 436 (4th Cir. 1961).

25 Janko v. United States, 281 F.2d 156, 167 (8th Cir. 1960). See also defense objection of a different sort in Burton v. United States, 196 U.S. 283, 305-06 (1905).

20 United States v. Rogers, 289 F.2d 433 (4th Cir. 1961).

27 Andrews v. United States, 309 F.2d 127 (5th Cir. 1962), cert. denied, 372 U.S. 946 (1963). 
the charge in which to reach agreement. It is questionable whether the accused's rights should ever rest upon such inexact considerations.

Reversal because the judge inquired into the numerical breakdown of the jury seems similarly imprecise. ${ }^{28}$ It ignores the fact that whether or not the judge knows how the jury is voting, the jurors themselves know how they stand. They are aware that, in using the Allen charge, the judge is addressing only a part of their number. Reversals based on such considerations are merely hedging admissions by the courts that the charge can be coercive.

Cases in which use of the charge has been upheld bear out the contention that review standards are uncertain and even arbitrary. In Huffman $v$. United States, ${ }^{29}$ the trial judge introduced thirteen separate factors, most of them clearly irrelevant, into the supplemental charge in an effort to "encourage" agreement. Among these were a recital of the "duty" to agree (a duty which, arguably, does not exist);30 the expense of the trial to the government and to taxpayers, the inconvenience to the judge and references to the fact that the jury had "no escape" from its responsibility to decide the case. The charge was upheld on appeal almost without comment by the majority, although one judge dissented vigorously. ${ }^{31}$

In Chase v. State ${ }^{32}$ the Alaska Supreme Court upheld the use of the Allen charge although the trial judge had been informed of both the numerical breakdown of the jury and the way the majority was voting. ${ }^{33}$ Though the Alaska court was not bound by Supreme Court holdings that the charge could not be used under such circumstances, Chase indicates that there are extreme differences of opinion as to what constitutes an abuse of discretion in the use of the charge.

At least one state has completely abandoned its version of the Allen instruction because of the difficulties encountered on review. The Ari-

28 This point has occasionally been recognized in Allen charge opinions. See United States v. Rogers, 289 F.2d 433, 435 (4th Cir. 1961).

29297 F.2d 754, 757 (5th Cir.) (Brown, J., dissenting), cert. denied, 370 U.S. 955 (1962).

30 Brown, J., dissenting in Huffman v. United States, supra note 29, at 759, said: "It is simply not legally correct that some jury must sometime decide that the defendant is 'guilty' or 'not gúilty. . . .' [A] succession of juries may legitimately fail to agree until, at long last, the prosecution gives up. But such juries, perhaps more courageous than any other, have performed their useful, vital function in our system. . . . It is in this independence that liberty is secured. . . I think a mistrial from a hung jury is a safeguard to liberty."

31 Ibid.

32369 P.2d 997 (Alaska 1962).

33 The jury foreman volunteered the information that there was an $11-1$ division, and asked the judge whether the deadlock "proved that the state had not proved its charge beyond a reasonable doubt and if the jury should now 'step down' to a lesser charge even if the majority felt that this should not be done." Id. at 1004. 
zona court, after a series of cases in which use of the charge had been evaluated on the merits, concluded that the instruction was impossible to administer uniformly and thus not in keeping with sound justice and the preservation of human liberties and security. ${ }^{34}$ The court pointed out that whenever the charge had been up for review, disposition had depended upon minute variations in fact situations surrounding use of the charge: "No rule of thumb can circumscribe definite bounds of when and where, or under what circumstances it should be given or refused. . . . We are convinced that the evils far outweigh the benefits, and decree that its use shall no longer be tolerated and approved by this court."35

There can be no doubt that the courts have been concerned with the problem of whether the Allen instruction can cause a juror to abandon his conscientious dissent and defer to the majority solely for the sake of reaching agreement. The uneasy acceptance of the charge is evident in the numerous cases in which slight changes of language or surrounding circumstances have tipped the scales toward a finding of error in its use. ${ }^{36}$ This judicial attitude indicates that it is time for a closer look at the charge and a consideration of alternatives more likely to insure a fair and impartial trial. Few would maintain that the trial judge should be required immediately to accept a jury's first indication of failure to agree without a fair attempt at encouraging agreement. It is only the method used to induce a verdict that is questionable. Total elimination of the Allen charge would bring its own problems; it would leave a void that would necessarily have to be filled in some way by the court. (Sending a jury back to its deliberations in stony silence might in itself be coercive.) ${ }^{37}$ Some have suggested that the charge be given along with the original instructions, so as to avoid the criticism that it is directed at only a part of the jury. It is difficult to see how this would do more than merely temper the objectionable qualities of the charge; it certainly would not detract from its basic impropriety. In any event, there would be no guarantee that such a use of the instruction would eliminate deadlocked juries.

Perhaps the most promising solution would be to adopt a substitute instruction which eliminated the objectionable qualities of the Allen charge. Such an instruction should, first of all, explain to the jury as

34 State v. Thomas, 86 Ariz. 161, 342 P.2d 197 (1959).

$35 I d$. at $166,342 \mathrm{P} .2 \mathrm{~d}$ at 200.

30 See cases cited supra, notes 7, 10.

37 The jurors naturally look to the court for approval and encouragement. Sending a jury back for additional deliberation in silence could be interpreted as an act of impatience of disapproval, and might intimidate a juror as effectively as would an urgent order from the court. to come to immediate agreement. 
a whole its duty to harmonize divergent views where possible, rather than addressing the minority alone. At least equal emphasis should be given to the point that each juror is entitled, in any event, to retain his conscientious convictions. ${ }^{38}$ An effective supplemental instruction, aimed not at forcing, but merely at encouraging agreement, could be formulated. Any loss of "efficiency" brought on by the more judicious wording could be attributed to a corresponding loss in coercive effect.

The charge employed in State $v$. Bozarth, ${ }^{30}$ while perhaps not perfect, furnishes a good starting point for the formulation of a substitute instruction:

Open and frank discussion by you in your jury room of the evidence in this case may aid you in agreeing upon the facts; however, no juror should ever agree to a verdict that violates the instructions of the court, nor find as a fact that which under the evidence and his conscience he believes to be untrue, yet each of you should respect the opinions of your fellow jurors as you would have them respect yours, and in the spirit of tolerance and understanding endeavor to bring the deliberations of the whole jury to an agreement upon a verdict. ${ }^{40}$

Such a substitute instruction should be made uniform for all courts within a jurisdiction, and language added by the judge should be prohibited. Uniformity, in this instance, could not work hardship if the instruction were properly noncommittal. If it is felt that a revised instruction would be so lacking in persuasiveness as to be useless, the alternative should be to prohibit any use of supplementary instructions, other than perhaps general urging to "try again." The Allen charge has admitted coercive potential, it is exceptionally difficult to cope with on appeal, and it may be a denial of the accused's right to a jury trial. So questionable a practice should not be permitted to continue.

38 This point is always dutifully covered in the Allen charge, but it is often given cursory or incidental treatment. It also is usually the first point mentioned, with the final (and most emphatic) part of the charge dwelling on the objectionable "heed the majority" theme.

39361 S.W.2d 819 (Mo. 1962).

$40 \mathrm{Id}$. at 826 . 